Perspective of Stress and Coping Behaviors

\title{
Pregnant Women's Perspective of Their Level of Stress and Coping Behaviors
}

\author{
Maha Mohamed El Sayed Gaafar, Assistant Professor \\ Psychiatric Nursing and Mental Health, Faculty of Nursing, Alexandria University \\ Maha Mohammed EL-Habashy, Assistant Professor \\ Obstetric and Gynecologic Nursing, Faculty of Nursing, Alexandria University \\ Fatma Abo Romia, Lecturer \\ Obstetric and Gynecologic Nursing, Faculty of Nursing, Tanta University
}

\begin{abstract}
Background: Pregnancy is an experience characterized by lack of adequate psychosocial resources. The presence of many stressors as work and family responsibilities make pregnancy a distant reflection of the ideal prototype. Objective: The present study aimed to identify pregnant women's perspective of their level of stress and coping behaviors. Setting: It was conducted at antenatal clinic of El-Shatby Maternity University Hospital. Subjects: The study comprised 100 pregnant women with normal pregnancy, free from medical diseases and willing to participate in the study. Tools: Three tools were utilized for data collection; a socio-demographic and reproductive history sheet, modified version of patient stress scale Wilson (1987), and modified version of coping scale Jalawic \& Powers (1981). Results: The study revealed that thirty two percent of the studied women had high level of stress, and about two third (61\%) of them had moderate level of stress. Problem oriented coping was highly used by half (51\%) of women, While affective oriented coping was moderately used by the majority (86\%) of studied pregnant women. Recommendations: Introducing the concept of early programming focusing on prenatal problems and stresses to improve health for all pregnant women was recommended. A better understanding of coping techniques used during healthy pregnancy can be used to design interventions that support a woman's positive coping techniques or suggest alternatives for negative coping techniques.
\end{abstract}

Keywords: pregnant women, stress, and coping behaviors. 


\section{Introduction}

Stress is simply a fact of nature. There are forces from the inside or outside world that affect the individual. Modern life is full of hassles, deadlines, frustrations, and demands. For many people, stress is so commonplace that it has become a way of life. For example, the stereotypical image of pregnancy experience is a happy and joyful time in life when a mother and her husband are expecting a child they planned to have. They are prepared to love and nurture, but changes in physique, self-identity, interpersonal relationships, and socioeconomic status may tax a woman's psychosocial and tangible resources and the resulting stress can affect maternal well-being. High prenatal stress increases the likelihood of preterm delivery and low birth-weight. Thus, one cannot describe the psychological experiences of pregnancy in any single way for women as a whole and it is vital to understand how women cope with stress during pregnancy ${ }^{(1,3)}$.

The notion that maternal emotions affect the developing fetus has been promulgated since biblical times. A convergent body of academic evidence supports maternal psychosocial factors as contributors to fetal development and pregnancy outcomes. Negative emotions, including maternal anxiety and perceived stress, are associated with reduced fetal heart rate variability, greater motor activity, alterations in state, and disturbances to fetal habituation. Affected outcomes include spontaneous abortions, pregnancy complications, shortened length of gestation, preterm delivery, and/or low birth weight. Moreover there is a smaller, but growing, body of evidence linking antenatal stress to more distal outcomes, including cognitive and behavioral functioning ${ }^{(4,5)}$.

In general, when people are stressed by something, their aim is to alter either the circumstances or their interpretation, in order to feel more comfortable; i.e. to cope ${ }^{(91)}$, thus coping can be defined as the cognitive, behavioral and emotional efforts to manage particular external and or internal demands that are appraised as taxing or exceeding the resources of the person"(6). Coping is influenced by both situational and intrapersonal factors. Available resources, competing demands, and the perceived controllability of a situation influence how an individual copes with stress. Coping is also associated with disposition. For example, optimism has been linked with particular ways of coping in pregnant women and in other populations. Coping is a dynamic process that responds to the changing course of stressful conditions. Multiple coping strategies may be employed, and people continuously reevaluate a situation to determine whether their coping efforts are succeeding. Individual coping styles can be shaped by some personal or socio-demographic factors and may remain 
relatively stable across the lifespan, the range and number of specific coping strategies can be constantly changing over the lifetime of individuals $^{(7-9)}$.

There are two basic coping styles, namely problem-focused versus emotion-focused. Problem-focused coping is directed at managing or changing the problem that causes stress. Emotion-focused coping, however, aims at regulating the emotional response to the problem. In general, problem-focused coping is suitable for controllable events, and emotion-focused coping is suitable for uncontrollable ones ${ }^{(10,11)}$.

Problem-focused efforts are often directed at defining the problem, generating alternative solutions, weighing the alternatives in terms of their costs and benefits, choosing among them, and acting. However, problem-focused coping embraces a wider array of problem-oriented strategies than problem solving alone. Problem-solving improve an objective, analytic process that is focused primarily on the environment; problem-focused also includes strategies that are directed inward: A number of different forms of problem focused coping have been identified including confronting (interpersonal) and cognitive (intrapersonal) forms of problem focused $\operatorname{coping}^{(12,13)}$.

Nurses have a crucial role in helping women's to recognize the strategies they are using to deal with stress by building women's awareness of the factors that create stress and feeling associated with stressful response, as well as can decide which stress can be omitted, avoided, or accepted and managed.

\section{Aim of the Study}

The aim of this study is to identify pregnant women's perspective of their level of stress and coping behaviors.

\section{Research Question}

How do women view their level of stress and the coping behaviors?

\section{Materials and Method}

\section{Materials}

Design: This study used a descriptive research design.

Settings: It was conducted at antenatal clinic of El- Shatby Maternity University hospital affiliated to University of Alexandria.

Subjects: The study comprised 100 pregnant women with normal pregnancy, attending the antenatal clinic, free from medical diseases and willing to participate in the study. The sample size was determined based on epi info program, using $10 \%$ acceptable error, 95\%confidence coefficient.

Tools: Three tools were utilized for data collection. 


\section{Tool (I): A socio-demographic and} reproductive history sheet

A structured interview data sheet, which was developed by the researchers. It involved data related to socio-demographic characteristics such as age, level of education, occupation, as well as family type and family income. It also comprised reproductive history such as gravidity, parity, number of abortions, spacing of pregnancies, and current period of gestation.

\section{Tool (II): A modified version of patient stress} scale

A modified version of patient stress scale, based on Neuman's health care system model. It was developed by Wilson $(1987)^{(16)}$. The scale was translated into the Arabic language and modified by Reda et al (1994) to suit the Egyptian women $^{(17,18)}$. The scale includes 20 statements with three points likert type scale ranging from 1 (not stressful) to 3 (very stressful). The degree of stress was categorized according to the following mean scores: low stress (20-32), moderate stress (33-45) and high stress (46-60).

It consisted of two parts; the first part includes extra personal stressors, and composed of 14 items referring to stressors in the women external environment (in a boundary of the women / women system and distal external environment). For example, feeling loss of control in what happened in the surroundings; absence of privacy, frequent blood analysis, presence of examination bed, and so on. The second part included interpersonal stressors and contained 6 items referring to stressors from the women external environment, which occur at the boundary between the women / women system and proximal external environment. For example, talking of staff with each other in present of the women, giving care without explaining any procedure, doing medical examination by more than one doctor.

\section{Tool (III): A modified version of coping scale}

A modified version of coping scale, developed by Jalawic \& Powers $(1981)^{(19)}$. The scale was translated into the Arabic language and modified by Reda et al (1994) to suit the Egyptian culture women ${ }^{(17,18)}$. The original scale consisted of 40 statements. The modified version contained 30 items that intended to identify the patient's coping behavior. It comprised two parts: the patient's problem-oriented coping methods, and the patient's affective oriented coping methods. The coping scale is a three point likert type scale ranging from 1 for low use, 2 for moderate use and 3 for high use.

The first part contained 8 items that identify the patient's problem-oriented coping methods used to solve a problem or to handle a stressful situation. The low use ranged from 8-12, the moderate use ranged from13-17 and high use ranged from 18-24. The second part consisted of 22 items that identify the patient's affective 
oriented coping methods. The low use ranged from 22-36, the moderate use ranged from3751 and high use ranged from 52-66.

\section{Method}

Permissions for data collection were obtained from the responsible authorities after explanation of the aim of the study. Tool I was developed by the researchers after extensive review of relevant and recent literature. Tool two and three were tested for content validity by a jury of 7 experts in psychiatric and mental health nursing as well as in obstetric and gynecologic nursing, to ascertain the appropriateness of items for measuring what they are supposed to measure.

A pilot study was carried out on 10 pregnant women, excluded from the study subjects to ascertain the relevance, clarity, and applicability of the tools as well as to detect any problem peculiar to the statements and estimate the time needed to complete the tools.

Data were collected through an individual interview, conducted in total privacy. The researcher interviewed the pregnant women who attend the antenatal clinical. Each interview lasted for 30 to 40 minutes according to cooperation of the women. Data was collected over a period of 4 months starting from the beginning of May until the end of August 2012.

\section{Ethical Considerations:}

The purpose of the study was explained to each pregnant woman and an informed written consent to participate in the study was obtained. Confidentiality of the collected data and the right to withdrew at any time were ensured.

\section{Statistical Analysis}

The collected data were categorized, coded, computerized, tabulated, and analyzed using the Statistical Package for Social Science (SPSS) software package version 13.0. The percentage, mean, and standard deviation were used to summarize data. The comparison between mean scores of groups was performed using $\mathrm{t}$ - test in case of comparison between two groups and F- test (analysis of variance) in case of comparison between more than two groups. The Post Hoc test (Scheffe) was used to specify which categories have a significant relation. The $\mathrm{p} \leq$ 0.05 was used to indicate statistical significance.

\section{Results}

Table (1) presents the socio-demographic characteristics of studied pregnant women. As regards age, $86 \%$ of the pregnant women the age above 20 years and 14\%were less than twenty years. Educational level revealed that about two third of the pregnant women (65\%) 
were either illiterate or had basic education, only $7 \%$ had university education. The table also illustrates that the vast majority of pregnant women $(86 \%)$, were housewives. About two third of the pregnant women (64\%) live in their nuclear family.

Table (2) shows the reproductive history of the studied pregnant women. Regarding gravidity $46 \%$ \& $43 \%$ of pregnant women had 2-3 \& 4-5 pregnancies respectively. However, $11 \%$ were primigravida. Parity ranged between 1- 3 deliveries among $73 \%$ of pregnant women, and between 4-5 deliveries among $8 \%$ of them. However, 19\% was primiparae. Abortion was not reported by the majority of pregnant women (83\%), Duration of spacing pregnancies was 1 year among almost one-quarter (26\%) of pregnant women, while it was 2 years among more than one-half $(56 \%)$ of them. However, spacing was not practiced by $7 \%$ of pregnant women. Period of gestation revealed that $28 \%$ of pregnant women were in their 2nd trimester of pregnancy, and $72 \%$ of them were in their 3rd trimester.

Table (3) illustrates studied pregnant women's level of stress and methods of coping. Regarding the level of stress, thirty two percent of the women had high level of stress, and about two third of them $(61 \%)$ had moderate level, only seven percent had low level of stress.
Concerning the women methods of coping with stress, problem oriented coping was highly used by half (51\%) of women, and moderately used by $(41 \%)$ of them. The mean use of problem oriented coping was $2.13 \pm$ 0.38. While affective oriented coping was used moderately by the majority of studied pregnant women (86\%), while it was highly used by $12 \%$ of them. The mean use of affective oriented coping was $1.93 \pm 0.24$.

Table (4) illustrates the relation between level of stress, and way of coping. It was observed that there is a negative relation between the level of stress and use of problem oriented method of coping, i.e. increase level of stress lead to less use of problem oriented coping method, with a statistical significant difference $r=-0.223$. While there was no statistical significant difference between the level of stress and use of affective oriented method of coping $r=0.012$.

Table (5) illustrates the relation between studied pregnant women's socio-demographic characteristics and their level of stress. Regarding age, the level of stress was found to be correlated significantly with the age of the pregnant women $F=14.381$. The Post Hoc test (Scheffe) indicate that there is a statistical significant relation between the level of stress and women with ages under 20 years when compared with women their age from 20 to less than 30 years and women their age more than 30 years. However, no statistical 
significant differences were found between level of stress and women's level of education, occupation, type of family, family income.

Table (6) represents the relation between studied pregnant women's obstetric history and their level of stress. The level of stress was found to be correlated significantly with all the women obstetric history. Regarding the gravity there is a statistical significant was found between the women who were in their first pregnancy when compared with women whose in their fourth or fifth pregnancies, and between the women who in their second and third pregnancies, $\mathrm{p}=0.004$ and, 0.012 respectively.

Concerning spacing of pregnancies, The Post Hoc test (Scheffe) indicate that there is a statistical significant relation between the level of stress and women who has two years as a space and the women who were in their first pregnancy $=0.046$.

Also, there was a statistical significant relation between the level of stress and women period of gestation. The women who were in their $2^{\text {nd }}$ trimaster had more feeling of stress than women in their $3^{\text {rd }}$ trimester, $\mathrm{t}=2.823$. The table shows that, the women who hasn't abortion before more stressed than women who had abortion, with a statistical significant relation $\mathrm{t}=5.162$. Regarding the parity, the women who haven't children more stressed when compared with women who had 2-3 children, and / or 4-5 children. A statistical significant relation were found $=0.017$ and 0.004 respectively.

Table (7) illustrates represents the relation between studied pregnant women's sociodemographic characteristics and their method of coping with stress. Firstly the problem oriented way of coping. Regarding age, the women whose age ranging from twenty to less than thirty, use problem oriented way of coping more than women whose age less than twenty years who use affective oriented way of coping . However, no statistical significant differences were found between level of education, occupation, type of family, family income and the women problem oriented way of coping.

Secondly the affective oriented way of coping with stress. It was clear that the mean score of using affective oriented way of coping with stress was significantly higher among working pregnant women than housewife pregnant women $\mathrm{t}=2.260$. The other socio-demographic characteristics as age, level of education, type of family, and family income have no statistical significant difference.

Table (8) illustrates the relation between studied pregnant women's obstetric history and their method of coping with stress. Firstly, the problem oriented way of coping with stress. Regarding the gravity, the women who were in their second or third pregnancies and fourth or fifth pregnancies use more problem oriented way of coping with stress than 
women in their first pregnancy, there were statistical significant difference were found between $\mathrm{p}<0.001$ for both.

Concerning spacing of pregnancies, the women who had no spacing between pregnancies use more problem oriented way of coping with stress than women who were in their first pregnancy, $\mathrm{p}=0.001$.also women who had two years space between pregnancies use more problem oriented way of coping with stress when compared with women who were in first pregnancy, $\mathrm{p}=0.001$. Regarding the parity, the women who had 1-3 children, use more problem oriented way of coping with stress when compared with women who haven't children. A statistical significant relation was found $\mathrm{p}=0.027$. The periods of gestation and number of abortion have no relation the problem oriented way of coping.

Secondly, the affective oriented way of coping with stress. Concerning spacing of pregnancies, the women who had one year spacing between pregnancies use more affective oriented way of coping with stress than women who were in their first pregnancy, or had two years spacing $\mathrm{p}=0.050$ and 0.043 respectively. Regarding the parity, the women who had 4-5 children, use more affective oriented way of coping with stress when compared with women who haven't children, or with women who had 1-3 children $\mathrm{p}=0.041$ and 0.020 respectively. While gravity, period of gestation and number of abortion, have no statistical significant difference were found.

\section{Discussion}

Pregnancy itself has the ability to cause a fair amount of stress, even when everything is just right. Stress affects the outcome of pregnancy. High levels of maternal stress in pregnancy contribute to adverse fetal, infant, child, and adult outcomes, including cognitive, emotional, neuro-developmental, and physical health effects ${ }^{(20)}$.

Appraising a stressor as a threat is associated with negative psychological and physical adjustment, whereas appraising a stressor as a challenge is associated with positive psychological and physical adjustment. There is also some evidence to suggest that the initial cognitive interpretation of a stress indirectly influences adjustment via the elicitation of certain coping methods ${ }^{(21)}$.

Although pregnancy is a happy experience yet, it is associated with a high level of stress as revealed by the results of the present study. This may be due to different concerns related to pregnancy outcome, labor, body image changes, role change and responsibilities. The present study also denote that coping strategies used by women to deal with stress include mainly problem oriented coping. These results are in accordance with studies who found that coping may be a link between psychological stress and pregnancy health. In this respect a study done on 159 healthy primigravidae, proved that women used prayer and preparation for motherhood 
(positive strategies) more frequently than avoidance behaviors and responding with negative emotion (negative strategies) ${ }^{(22)}$. In this respect, Gourounti et al (2012) stated that pregnancy and birth are times of great emotional and spiritual sensitivity, even when both mother and baby are healthy ${ }^{(23)}$.

Several other studies have linked level of stress of pregnant women with pregnancy health and outcome, yet. Results are inconsistent A study done to assess the degree of stress experienced by pregnant adolescents, a majority of the respondents reported experiencing dysphoric affect in response to stress. Those within the sample who reported experiencing the highest degree of stress also reported a greater degree of anger and frustration as well as dysphoria ${ }^{(24)}$.

This study revealed that certain factors affect women perspective of their level of stress as well as their coping. Thus it was found that, the level of stress is significantly affected by women's obstetric history as gravidity, spacing between pregnancy, parity, period of gestation, and number of abortion. This is matched with another study which found that women experiencing multiple pregnancies had more stress and worry. This is especially so if they have experienced infertility and the pregnancy were achieved with the assistance of modern infertility treatments. In this situation, some of the women have been extremely anxious and have required a lot of support and reassurance ${ }^{(25)}$. Cote-Arsenault, et al (2001) in a study that looked at the specific emotions and concerns of women who were pregnant after a perinatal loss, found that anxiety, nervousness and feeling scared were the most frequent emotions reported $^{(26)}$. The result of the present study also revealed that the women in their first pregnancy had significantly higher level of stress than women in their 4-5 pregnancies. The researchers think, this may be because the pregnant women feel secure and that the situation will pass smoothly, and based on previous experience she has the necessary skills to manage minor discomfort.

Moreover, perinatal loss has an impact on the subsequent pregnancy as reported in the study of Hill et al (2008). His study revealed that a pregnancy after a perinatal loss is a time full of intense emotions for expectant mothers. Anxiety, nervousness, and feeling scared were the most frequent emotions reported by these women $^{(6)}$. This study contradicts the result of the present study, where women who have not experienced abortion before are more stressed than women who had abortion. It has also been found women who have had a previous perinatal loss can also be highly anxious in the next pregnancy especially in the third trimester.

In the present study, the pregnant women below the age of twenty experience significantly higher level of stress when 
compared with women aged more than twenty and this level of stress decreased by increased age. This may be due to by age, the women gain experience how to manage different situations effectively. It was also observed that level of stress is higher in nonworking women than working women. We think that work is vital for any person to elevate self-esteem, self-confidence; sense of achievement. Also work increases the women experience in dealing with different stressful situation. This result was consistent with some studies which prove that, the majority of women encounter only minor difficulties and regard working in a positive way. However, for a minority of women working during pregnancy adversely affects their well-being. The literature suggests that working during pregnancy has still to be accepted and accommodated by employers and colleagues.

In relation to coping, the present study proved that, there was a significant negative relation between the level of stress and use of problem oriented method of coping, i.e. increase level of stress lead to less use of problem oriented coping method. And no significant difference between the level of stress and use of affective oriented method of coping. The problem oriented coping mean take action to face stress, affective oriented coping is one of the large groups of coping that consists of cognitive processes directed at lessening emotional distress, and it is aimed at managing emotional responses to stressors. It includes strategies such as wishful thinking, distancing, emphasizing the positive; selfblame, tension-reduction and self-isolation ${ }^{(27)}$.

A study done by Kathleen (2005) indicated that women used prayer and preparation for motherhood (positive strategies) more frequently than avoidance behaviors and responding with negative emotion (negative strategies). Multivariate analysis controlling for potential confounders indicated that younger age, more education, and pregnancy distress correlated with more frequent use of the positive coping strategy preparation for motherhood. Higher life event stress, more depressive symptoms, and high pregnancy distress were associated with frequent use of avoidance behaviors. Women with fewer depressive symptoms frequently used positive appraisal of the pregnancy as a coping strategy. Non-white women and women with high pregnancy distress used prayer as a coping strategy more frequently than white women or women with low pregnancy distress. Non-white women and women with lower levels of depressive symptoms used task coping (taking action) more frequently than white women or women with high depression symptoms. Depression and pregnancy distress were positively related to responding with negative emotions. Younger age, non-white race, and fewer 
Perspective of Stress and Coping Behaviors

stressful life events were associated with frequent use of distraction coping ${ }^{(29)}$.

\section{Conclusion}

A crucial aspect of helping women to cope with their difficulties is the assessment of their coping strategies and consideration of the unique meaning of the stressful situation to them.

A better understanding of coping techniques used during healthy pregnancy can be used to design interventions that support a woman's positive coping techniques or suggest alternatives for negative coping techniques. The goal is to improve pregnancy health for all women.

Clinical nurse practitioners should be sensitive to individual differences in how clients appraise, explain, and cope with stressors. Moreover, it may be clinically beneficial to focus on the initial cognitive interpretations related to perception of stressful situations.

\section{Recommendations}

Psycho-educational programs for pregnant women about stress, causes, and the effect of stress on self and fetus.

Psych-educational programs to educate the women and their families about adaptive and maladaptive way of coping with stress.

Further researches should be done to increase understanding the complexity of stresses of pregnant women and their way of coping. 
Table (1): Distribution of studied pregnant women according to their socio-demographic characteristics

\begin{tabular}{||c|c|c|}
\hline $\begin{array}{c}\text { Socio-demographic } \\
\text { characteristics }\end{array}$ & No (100) & \% \\
\hline Age (years): & 14 & 14.00 \\
< 20 & 43 & 43.00 \\
$20-$ & 43 & 43.00 \\
$30+$ & & \\
Level of education: & 31 & 31.00 \\
- Illiterate & 34 & 34.00 \\
- Basic & 28 & 28.00 \\
- Secondary & 7 & 07.00 \\
- University & & \\
\hline Occupation: & 86 & 86.00 \\
- Housewife & 14 & 14.00 \\
- Working & 64 & 64.00 \\
\hline Type of family: & 36 & 36.00 \\
- Nuclear & & \\
- Extended & & \\
\hline
\end{tabular}

Table (2): Distribution of studied pregnant women according to their obstetric history

\begin{tabular}{|l|c|c|}
\hline \multicolumn{1}{|c|}{ Reproductive history } & No & $\%$ \\
\hline Gravidity: & 11 & 11.00 \\
1 & 46 & 46.00 \\
$2-$ & 43 & 43.00 \\
$4-5$ & & \\
\hline Parity: & 19 & 19.00 \\
0 & 73 & 73.00 \\
$1-$ & 8 & 08.00 \\
$4-5$ & & \\
Number of abortions: & 83 & 83.00 \\
0 & 17 & 17.00 \\
$1-3$ & 7 & 07.00 \\
\hline Spacing of pregnancies (year): & 26 & 26.00 \\
No spacing & 56 & 56.00 \\
1 & 11 & 11.00 \\
2 & & 28.00 \\
Not applicable (1 ${ }^{\text {st }}$ pregnancy) & 28 & 72.0 \\
\hline Period of gestation (trimester): & 72 & \\
$2^{\text {nd }}$ & & \\
3rd & & \\
\hline
\end{tabular}


Perspective of Stress and Coping Behaviors

Table (3): Distribution of studied pregnant women according to their level of stress and methods of coping

\begin{tabular}{|c|c|c|}
\hline $\begin{array}{c}\text { Level of stress \& methods of } \\
\text { coping }\end{array}$ & No (100) & $\%$ \\
\hline $\begin{array}{l}\text { Level of stress: } \\
-\quad \text { low } \\
-\quad \text { Moderate } \\
-\quad \text { High }\end{array}$ & $\begin{array}{c}7 \\
61 \\
32\end{array}$ & $\begin{array}{c}7 \\
61 \\
32\end{array}$ \\
\hline $\begin{array}{l}\text { Range of score(1-3) } \\
\text { Mean } \pm \text { SD }\end{array}$ & \multicolumn{2}{|c|}{$\begin{array}{l}1.43-3.00 \\
2.23 \pm 0.39\end{array}$} \\
\hline $\begin{array}{l}\text { Coping methods: } \\
\text { Problem oriented coping: } \\
\quad-\text { Low } \\
- \text { Moderate } \\
- \text { High }\end{array}$ & $\begin{array}{c}8 \\
41 \\
51\end{array}$ & $\begin{array}{l}10.0 \\
39.0 \\
51.0\end{array}$ \\
\hline $\begin{array}{l}\text { Range of score(1-3) } \\
\text { Mean } \pm \text { SD }\end{array}$ & \multicolumn{2}{|c|}{$\begin{array}{l}1.00-2.88 \\
2.13 \pm 0.38\end{array}$} \\
\hline $\begin{array}{l}\text { Affective oriented coping: } \\
\quad-\text { Low } \\
-\quad \text { Moderate } \\
-\quad \text { High }\end{array}$ & $\begin{array}{c}2 \\
86 \\
12\end{array}$ & $\begin{array}{l}08.0 \\
84.0 \\
08.0\end{array}$ \\
\hline $\begin{array}{l}\text { Range of score(1-3) } \\
\text { Mean } \pm \text { SD }\end{array}$ & \multicolumn{2}{|c|}{$\begin{array}{l}1.23-2.68 \\
1.93 \pm 0.24\end{array}$} \\
\hline
\end{tabular}


Table (4): Relation between level of stress and methods of coping of studied pregnant women.

\begin{tabular}{||l|c|c||}
\hline \multirow{2}{*}{\multicolumn{1}{|c|}{ Coping methods }} & \multicolumn{2}{c||}{ Level of stress } \\
\cline { 2 - 3 } & $\mathrm{r}$ & $\mathrm{P}$ \\
\hline Problem oriented coping & $-0.223^{*}$ & 0.026 \\
\hline Affective oriented coping & 0.012 & 0.903 \\
\hline
\end{tabular}

r: Pearson coefficient $\quad *$ Statistically significant at $\mathrm{p} \leq 0.05$

Table (5): Relationship between studied pregnant women's socio-demographic characteristics and their level of stress

\begin{tabular}{|c|c|c|c|}
\hline \multirow{2}{*}{$\begin{array}{c}\text { Socio-demographic } \\
\text { characteristics }\end{array}$} & \multicolumn{2}{|c|}{ Level of stress } & \multirow{2}{*}{ Significance test } \\
\hline & Range & Mean \pm SD & \\
\hline $\begin{array}{l}\text { Age (years): } \\
\quad<20 \\
20- \\
30+\end{array}$ & $\begin{array}{l}1.64-3.00 \\
1.50-2.86 \\
1.43-3.86\end{array}$ & $\begin{array}{l}2.68 \pm 0.35 \\
2.20 \pm 0.36 \\
2.11 \pm 0.33\end{array}$ & $\begin{array}{l}\mathrm{F}=14.381 \\
\mathrm{p}=0.001 *\end{array}$ \\
\hline $\mathrm{P}$ & \multicolumn{2}{|c|}{$\mathrm{p}_{1}<0.001^{*}, \mathrm{p}_{2}<0.001^{*}, \mathrm{p}_{3}=0.497$} & \\
\hline $\begin{array}{l}\text { Level of education: } \\
-\quad \text { Illiterate } \\
-\quad \text { Basic } \\
-\quad \text { Secondary } \\
-\quad \text { University }\end{array}$ & $\begin{array}{l}1.43-3.00 \\
1.57-3.00 \\
1.50-2.86 \\
2.29-2.64\end{array}$ & $\begin{array}{l}2.19 \pm 0.40 \\
2.30 \pm 0.41 \\
2.12 \pm 0.36 \\
2.49 \pm 0.11\end{array}$ & $\begin{array}{l}F=2.292 \\
p=0.083\end{array}$ \\
\hline $\begin{array}{l}\text { Occupation: } \\
\quad-\text { Housewife } \\
- \text { Working } \\
\end{array}$ & $\begin{array}{c}1.43-3.0 \\
1.50-2.93 \\
\end{array}$ & $\begin{array}{l}2.24 \pm 0.39 \\
2.16 \pm 0.40 \\
\end{array}$ & $\begin{array}{l}\mathrm{t}=0.738 \\
\mathrm{p}=0.462\end{array}$ \\
\hline $\begin{array}{c}\text { Type of family: } \\
-\quad \text { Nuclear } \\
-\quad \text { Extended } \\
\end{array}$ & $\begin{array}{l}1.50-3.00 \\
1.43-3.00 \\
\end{array}$ & $\begin{array}{l}2.24 \pm 0.37 \\
2.21 \pm 0.42 \\
\end{array}$ & $\begin{array}{l}\mathrm{t}=0.371 \\
\mathrm{p}=0.711\end{array}$ \\
\hline
\end{tabular}

F: F test (ANOVA)

t: Student t-test

*: Significant at $\mathbf{p} \leq \mathbf{0 . 0 5}$

$p_{1}: p$ value of Post Hoc test (Scheffe) between $1^{\text {st }}$ category and $2^{\text {nd }}$ category

$\mathrm{p}_{2}: \mathrm{p}$ value of Post Hoc test (Scheffe) between $1^{\text {st }}$ category and $3^{\text {rd }}$ category

$\mathrm{p}_{3}: \mathrm{p}$ value of Post Hoc test (Scheffe) between $2^{\text {nd }}$ category and $3^{\text {rd }}$ category 
Table (6): Relationship between studied pregnant women's Reproductive data and their level of stress

\begin{tabular}{|c|c|c|c|}
\hline \multirow[t]{2}{*}{ Reproductive data } & \multicolumn{2}{|c|}{ Level of stress } & \multirow[t]{2}{*}{$\begin{array}{c}\text { Significance } \\
\text { Test }\end{array}$} \\
\hline & Range & Mean \pm SD & \\
\hline $\begin{array}{l}\text { Gravidity: } \\
\begin{array}{l}1 \\
2-3 \\
4-5\end{array}\end{array}$ & $\begin{array}{l}1.43-3.0 \\
1.57-2.93 \\
1.43-2.64\end{array}$ & $\begin{array}{l}2.50 \pm 0.54 \\
2.31 \pm 0.36 \\
2.07 \pm 0.31\end{array}$ & $\begin{array}{l}\mathrm{F}=8.044 \\
\mathrm{p}=0.001 *\end{array}$ \\
\hline $\mathrm{P}$ & \multicolumn{2}{|c|}{$\mathrm{p} 1=0.307, \mathrm{p} 2=0.004, \mathrm{p} 3=0.012$} & \\
\hline $\begin{array}{l}\text { Spacing of pregnancies (year): } \\
\text { No spacing } \\
1 \\
2 \\
\text { Not applicable } \\
\end{array}$ & $\begin{array}{c}1.93-2.86 \\
1.43-2.93 \\
1.57-2.86 \\
1.43-3.0 \\
\end{array}$ & $\begin{array}{l}2.52 \pm 0.30 \\
2.22 \pm 0.41 \\
2.15 \pm 0.32 \\
2.50 \pm 0.54 \\
\end{array}$ & $\begin{array}{c}\mathrm{F}=4.310 \\
\mathrm{p}=0.007 *\end{array}$ \\
\hline $\mathrm{P}$ & \multicolumn{2}{|c|}{$\begin{array}{l}\mathrm{p}_{1}=0.306, \mathrm{p}_{2}=0.106, \mathrm{p}_{3}=1.000 \\
\mathrm{p}_{4}=0.886, \mathrm{p}_{5}=0.222, \mathrm{p}_{6}=0.046\end{array}$} & \\
\hline $\begin{array}{l}\text { Period of gestation (trimester): } \\
2^{\text {nd }} \\
3^{\text {rd }}\end{array}$ & $\begin{array}{l}1.64-3.00 \\
1.43-2.93\end{array}$ & $\begin{array}{l}2.40 \pm 0.40 \\
2.16 \pm 0.37\end{array}$ & $\begin{array}{c}\mathrm{t}=2.823 \\
\mathrm{p}=0.006\end{array}$ \\
\hline $\begin{array}{l}\text { Number of abortions: } \\
0 \\
1-3 \\
\end{array}$ & $\begin{array}{c}1.43-3.0 \\
1.50-2.36\end{array}$ & $\begin{array}{l}2.29 \pm 0.39 \\
1.95 \pm 0.21 \\
\end{array}$ & $\begin{array}{c}\mathrm{t}=5.162 \\
\mathrm{p}<0.001 *\end{array}$ \\
\hline $\begin{array}{c}\text { Parity: } \\
0 \\
1-3 \\
4-5\end{array}$ & $\begin{array}{l}1.43-3.0 \\
1.43-2.93 \\
1.71-2.36 \\
\end{array}$ & $\begin{array}{l}2.47 \pm 0.46 \\
2.20 \pm 0.35 \\
1.95 \pm 0.22\end{array}$ & $\begin{array}{c}\mathrm{F}=6.781 \\
\mathrm{p}=0.002 *\end{array}$ \\
\hline $\mathrm{P}$ & \multicolumn{2}{|c|}{$\mathrm{p}_{1}=0.017^{*}, \mathrm{p}_{2}=0.004^{*}, \mathrm{p}_{3}=0.195$} & \\
\hline
\end{tabular}

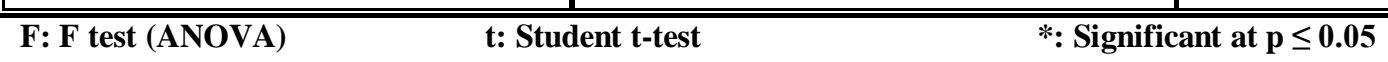

$\mathrm{p}_{1}$ : $\mathrm{p}$ value of Post Hoc test (Scheffe) between $1^{\text {st }}$ category and $2^{\text {nd }}$ category

$\mathrm{p}_{2}: \mathrm{p}$ value of Post Hoc test (Scheffe) between $1^{\text {st }}$ category and $3^{\text {rd }}$ category

$\mathrm{p}_{3}: \mathrm{p}$ value of Post Hoc test (Scheffe) between $1^{\text {st }}$ category and $4^{\text {th }}$ category

$\mathrm{p}_{4}$ : $\mathrm{p}$ value of Post Hoc test (Scheffe) between $2^{\text {nd }}$ category and $3^{\text {rd }}$ category

$p_{5}: p$ value of Post Hoc test (Scheffe) between $2^{\text {nd }}$ category and $4^{\text {th }}$ category

$\mathrm{p}_{6}$ : $\mathrm{p}$ value of Post Hoc test (Scheffe) between $3^{\text {rd }}$ category and $4^{\text {th }}$ category 
Table (7): Relationship between pregnant women's socio-demographic characteristics and their coping methods with stress

\begin{tabular}{|c|c|c|}
\hline \multirow[t]{2}{*}{ Socio-demographic characteristics } & $\begin{array}{c}\text { Problem } \\
\text { oriented coping }\end{array}$ & $\begin{array}{c}\text { Affective } \\
\text { oriented coping }\end{array}$ \\
\hline & Mean \pm SD & Mean \pm SD \\
\hline $\begin{array}{l}\text { Age (years): } \\
\quad<20 \\
20- \\
30+\end{array}$ & $\begin{array}{l}1.88 \pm 0.39 \\
2.18 \pm 0.41 \\
2.15 \pm 0.32\end{array}$ & $\begin{array}{l}2.05 \pm 0.29 \\
1.89 \pm 0.20 \\
1.93 \pm 0.25\end{array}$ \\
\hline $\begin{array}{l}\mathrm{F} \\
\mathrm{p}\end{array}$ & $\begin{array}{c}3.722 \\
0.028^{*}\end{array}$ & $\begin{array}{l}2.388 \\
0.097\end{array}$ \\
\hline Post Hoc test (Scheffe) & $\begin{array}{c}\mathrm{p}_{1}=0.027^{*}, \mathrm{p}_{2}=0.308 \\
\mathrm{p}_{3}=0.989\end{array}$ & ------------ \\
\hline $\begin{array}{l}\text { Level of education: } \\
-\quad \text { Illiterate } \\
-\quad \text { Basic } \\
-\quad \text { Secondary } \\
-\quad \text { University }\end{array}$ & $\begin{array}{l}2.00 \pm 0.51 \\
2.13 \pm 0.29 \\
2.25 \pm 0.31 \\
2.18 \pm 0.27\end{array}$ & $\begin{array}{l}1.86 \pm 0.26 \\
1.96 \pm 0.24 \\
1.96 \pm 0.24 \\
1.97 \pm 0.20\end{array}$ \\
\hline $\begin{array}{l}\mathrm{F} \\
\mathrm{p}\end{array}$ & $\begin{array}{l}2.157 \\
0.098\end{array}$ & $\begin{array}{l}1.141 \\
0.336\end{array}$ \\
\hline $\begin{array}{l}\text { Occupation: } \\
- \text { Housewife } \\
- \text { Working } \\
\end{array}$ & $\begin{array}{l}2.11 \pm 0.38 \\
2.21 \pm 0.37\end{array}$ & $\begin{array}{l}1.91 \pm 0.23 \\
2.06 \pm 0.30\end{array}$ \\
\hline $\begin{array}{l}\mathrm{t} \\
\mathrm{p}\end{array}$ & $\begin{array}{l}0.848 \\
0.399 \\
\end{array}$ & $\begin{array}{l}2.260 \\
0.026^{*}\end{array}$ \\
\hline $\begin{array}{c}\text { Type of family: } \\
-\quad \text { Nuclear } \\
-\quad \text { Extended }\end{array}$ & $\begin{array}{l}2.19 \pm 0.33 \\
2.01 \pm 0.44\end{array}$ & $\begin{array}{l}1.96 \pm 0.22 \\
1.88 \pm 0.27\end{array}$ \\
\hline $\begin{array}{l}\mathrm{t} \\
\mathrm{p}\end{array}$ & $\begin{array}{l}2.316 \\
0.078\end{array}$ & $\begin{array}{l}1.513 \\
0.134\end{array}$ \\
\hline
\end{tabular}

F: F test (ANOVA) t: Student t-test

*: Significant at $\mathbf{p} \leq \mathbf{0 . 0 5}$

$\mathrm{p}_{1}$ : $\mathrm{p}$ value of Post Hoc test (Scheffe) between $1^{\text {st }}$ category and $2^{\text {nd }}$ category

$\mathrm{p}_{2}: \mathrm{p}$ value of Post Hoc test (Scheffe) between $1^{\text {st }}$ category and $3^{\text {rd }}$ category

$\mathrm{p}_{3}$ : $\mathrm{p}$ value of Post Hoc test (Scheffe) between $2^{\text {nd }}$ category and $3^{\text {rd }}$ category 
Table (8): Relationship between pregnant women's Reproductive history and their coping methods with stress

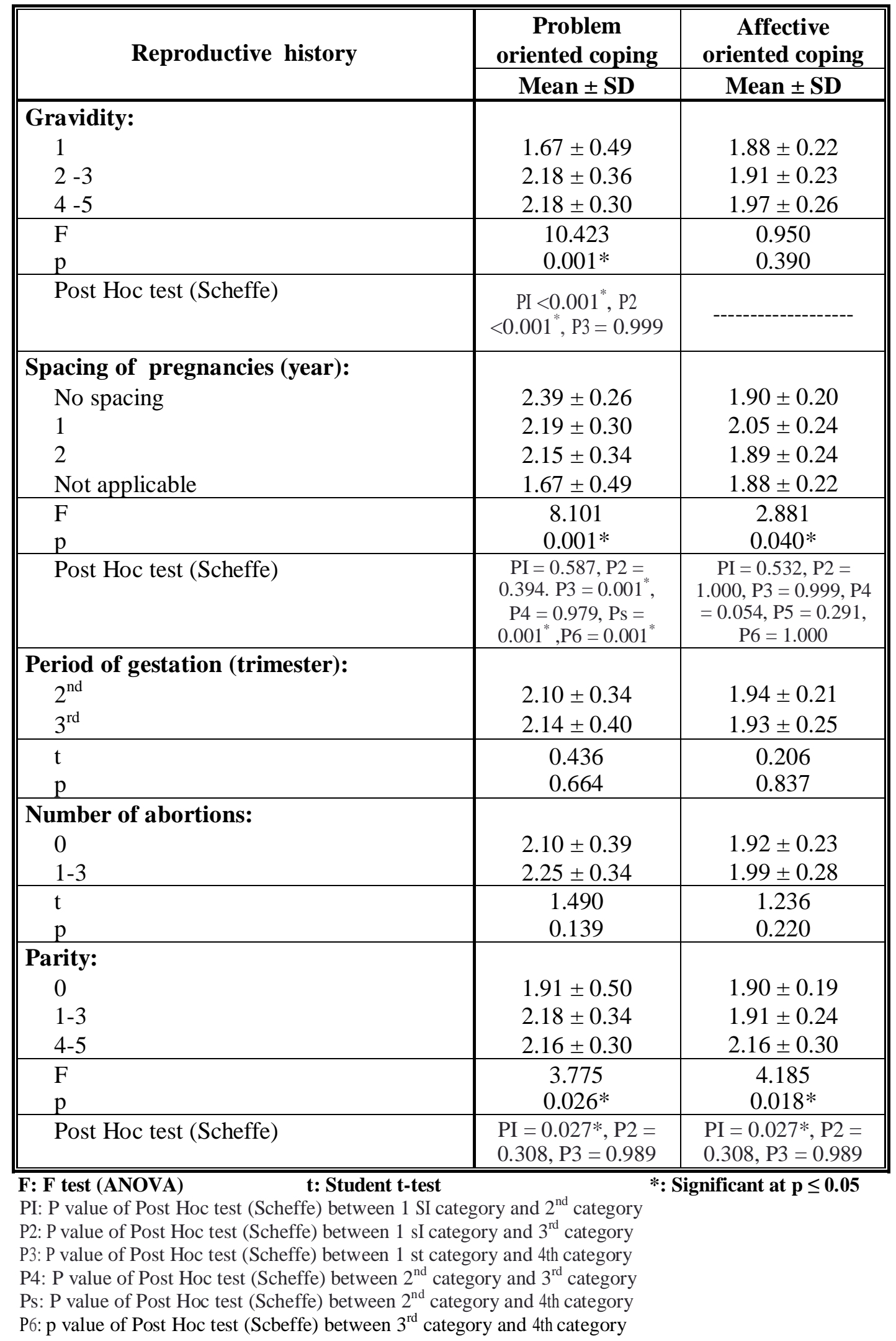




\section{References}

1. Schetter C. Psychological science on pregnancy: stress processes, biopsychosocial models, and emerging research issues. Annu Rev Psychol 2011; 62:531-58.

2. DiPietro J, Ghera M, Costigan K and Hawkins M. Measuring the ups and downs of pregnancy stress. J Psychosom Obstet Gynecol 2004; 25:189-201.

3. Hamilton $\mathbf{J}$ and lobel $\mathbf{M}$. Types, patterns, and predictors of coping with stress during pregnancy: examination of the revised prenatal coping inventory in a diverse sample. Journal of Psychosomatic Obstetrics \& Gynecology 2008; 29(2): 97-104.

4. Scott E, What coping strategies are effective? November 05, 2009. Available at: http://stress.about.com/od/ frequently asked questions/f/ coping strategies. Htm. (Retrieved on: 29 June 2012).

5. Kilburn. S, Moskowitz J. "coping: pitfalls and promise." Annual review of psychology; 2004, 55: 745-74.

6. Hill P, DeBackere K, and Kavanaugh K.The Parental Experience of Pregnancy after Perinatal Loss. J Obstet Gynecol Neonatal Nurs 2008 Sep-Oct; 37(5): 525-37.

7. Lobel M, Hamilton $\mathrm{J}$ and, Cannella D. Psychosocial Perspectives on Pregnancy: Prenatal Maternal Stress and Coping.
Social and Personality Psychology Compass 2008 July; 2 (4): 1600- 23.

8. O'Connor $\mathrm{T}$ Heron J, Goulding $\mathrm{J}$ and Glover V. (2003). Maternal antenatal anxiety and behavioral/emotional problems in children: a test of programming hypotheses. J Child Psychol Psychiatry 2003; 44 (7): 102536.

9. Lobel M, DeVincent CJ, Kaminer A, and Meyer B. The impact of prenatal maternal stress and optimistic disposition on birth outcomes in medically high-risk women. Health Psychol 2000 Nov; 19 (6):544-53 .

10. O'Connor T, Heron J, Golding J, Beveridge $\mathrm{M}$ and Glover V. Maternal antenatal anxiety and children's behavioral/emotional problems at 4 years: Report from the Avon Longitudinal Study of Parents and Children. Br J Psychiatry 2002; 180: $502-8$

11. Monk, C, Myers M, Sloan R, Ellman L and Fifer W. The effects of women's stress-elicited physiological activity and chronic anxiety on fetal heart rate. Journal of Development and Behavioral Pediatrics 2003; 24:32-8.

12. Folkman S, Lazarus RS, Pimey S, Novacek J, Age difference in stress and coping processes. Psychology and Aging 1987; 2(2):171-84. 
13. Aitken A, Crawford L. Coping with stress: dispositional coping strategies of project managers. International Journal of Project Management 2007; 25(7): 666-73.

14. Lequerica $\mathrm{AH}$, Forch-heimer $\mathrm{M}$, Tate DG, Roller S. Ways of coping and perceived stress in women with spinal cord injury. Journal of health psychology 2008; 13(3): 348-54.

15. Naeeum MM, Relationship between coping styles and level of depression among depressed patients. Unpublished thesis, Alexandria University, 2011.

16. Wilson V. Identification of stressors related to patient's psychological responses to surgical intensive care unit. Heart and Lung 1987; 16(3):267-73.

17. Reda N, El Soussi A, El Gueneidy M and Hafez A. Psychological and physical stress responses and coping patterns of the critically ill patients. Tanta medical journal 1994; 22(1).

18. El habashy M. the effect of a teaching program on stress responses and coping behaviors of infertile women after in vitro fertilization. Unpublished Doctor Thesis, faculty of Nursing, Alexandria University, Egypt, 1999.

19. Jalawic A, Powers M. Stress and coping in hypertensive and emergency room patients. Nursing Research 1981; 30: 1015.
20. Mueller BR, Bale TL. Early prenatal stress impact on coping strategies and learning performance is sex dependent. Physiology \& Behavior 91 (2007) 5565.

21. Scott C, Roesch, Bernard Weiner; Allison A. Vaughn. Cognitive Approaches to Stress and Coping. Curr Opin Psychiatry. 2002; 15(6).

22. Hamilton J, Lbel M. Types, patterns, and predictors of coping with stress during pregnancy: Examination of the Revised Prenatal Coping Inventory in a diverse sample, Journal of Psychosomatic Obstetrics \& Gynecology, June 2008; 29(2): 97-104.

23. Gourounti,K, Anagnostopoulos F. Potamianos,G Lykeridou,K Schmidt,L Vaslamatzis,G. Perception of control, coping and psychological stress of infertile women undergoing IVF Reproductive BioMedicine Online 2012; 24, 670-79.

24. DiPietro J, Ghera M, Costigan K, Hawkins M." Measuring the ups and downs of pregnancy stress". J Psychosom Obstet Gynecol 2004; 25:189-201.

25. Bergner, A., Beyer, R., Klapp, B.F., Rauchfuss, M., Pregnancy after early pregnancy loss: a prospective study of anxiety, depressive symptomatology and coping. Journal of Psychosomatic 
Obstetric and Gynecology2008; 29, 105113.

26. Côté-Arsenault D, Bidlack D, and Humm A. Women's emotions and concerns during pregnancy following perinatal loss. MCN Am J Matern Child Nurs. 2001 May-Jun; 26(3):128-34.

27. Lobel, M., Hamilton, J.G.and Cannella, D.T."Psychosocial Perspectives on
Pregnancy: Prenatal Maternal Stress and Coping" Department of Psychology, Stony Brook University (May 2008)(3).

28. Elizabeth S. What Coping Strategies Are Effective? About.com Guide Updated November 05, 2009 About.com Health's Disease and Condition content is reviewed by the Medical Review Board (4). 